\title{
Pharmaceutical Phonies: The Entanglement of Fraud, Third-Party Payors, and Proximate Cause in Civil RICO Cases
}

Merrick Max Dillard Hayashi

Texas A\&M University School of Law (Student), maxhayashi@tamu.edu

\section{Recommended Citation}

Merrick Max Dillard Hayashi, Pharmaceutical Phonies: The Entanglement of Fraud, Third-Party Payors, and Proximate Cause in Civil RICO Cases, 9 Tex. A\&M L. Rev. Arguendo 1 (2021).

Available at: https://doi.org/10.37419/LR.V9.Arg.1

This Arguendo (Online) is brought to you for free and open access by Texas A\&M Law Scholarship. It has been accepted for inclusion in Texas A\&M Law Review by an authorized editor of Texas A\&M Law Scholarship. For more information, please contact aretteen@law.tamu.edu. 


\title{
Pharmaceutical Phonies: The Entanglement of Fraud, Third-Party Payors, and Proximate Cause in Civil Rico Cases
}

\author{
by: Merrick M. Hayashi*
}

\section{INTRODUCTION}

This Case Note analyzes the Ninth Circuit's approach to the issue of whether patients and doctors destroy proximate cause in cases where third-party payors ("TPPs") sue drug companies for fraudulently misrepresenting the health risks associated with their products. In the 2019 case Painters \& Allied Trades District Council 82 Health Care Fund v. Takeda Pharmaceuticals Co., the Ninth Circuit held that TPPs suing to recover damages from a pharmaceutical company for the fraudulent omission of a drug's health risks could satisfy the proximate cause requirement for a civil cause of action under $\S 1964$ (c) of the Racketeer Influenced and Corrupt Organizations Act (“RICO”). ${ }^{1}$

The Ninth Circuit's decision is satisfactory in that it faithfully (1) observes the Supreme Court's direct relation test and (2) follows precedent establishing that a plaintiff satisfies the proximate cause requirement when their alleged injury is a foreseeable and natural consequence of the defendant's fraud. As a matter of public policy, this holding is positive because it hamstrings pharmaceutical companies' ability to escape liability by hiding behind patients, doctors, and other actors inhabiting the chain of causation. Additionally, the Ninth Circuit's holding is positive in that it adheres to Supreme Court precedent and helps deter future injurious conduct.

DOI: https://doi.org/10.37419/LR.V9.Arg.1

* J.D. Candidate, Texas A\&M University School of Law, May 2023; B.S. in Biochemistry, Baylor University, May 2018. The Author would like to thank his parents, Julia and Stuart Hayashi, for their continuous support. The Author would also like to thank Professor Brian Larson for his approachability, kindness, and diligence in helping the Author develop his legal writing skills.

${ }^{1}$ Painters \& Allied Trades Dist. Council 82 Health Care Fund v. Takeda Pharms. Co., 943 F.3d 1243, 1260 (9th Cir. 2019), writ denied, 141 S. Ct. 86 (2020); 18 U.S.C. § 1964(c). 
In support of these assertions, this Case Note begins by examining the factual background and procedural posture of Painters. The Note continues by analyzing the majority's opinion with respect to related case law and closes by suggesting ways to address some of the potential problems that could stem from the Ninth Circuit's decision.

\section{FACTUAL BACKGROUND OF PAINTERS}

In 1999, Takeda Pharmaceuticals USA, Inc., Takeda Pharmaceutical Company Ltd., and Eli Lilly \& Co. ("Defendants") received approval from the Food and Drug Administration ("FDA") for Actos, a drug designed to reduce blood sugar in type 2 diabetics. ${ }^{2}$ Over the next several years, Defendants marketed and sold Actos despite an accrual of data suggesting that the drug increased a patient's risk of developing bladder cancer. ${ }^{3}$ Rather than heeding the data, Defendants refused to add a warning label to Actos or warn the public of its risk, opting instead to convince consumers that Actos did not predispose users to an increased likelihood of developing bladder cancer. ${ }^{4}$

In September 2010, the FDA conducted a safety review of the drug's alleged carcinogenic properties. ${ }^{5}$ Less than a year thereafter, the FDA issued an official warning to the public describing Actos's potential link to bladder cancer in patients. ${ }^{6}$ In response, Defendants appended a warning label to Actos warning of its potential risks, resulting in an $80 \%$ decrease in sales. $^{7}$

In 2017, five diabetic patients (“Patients”), who took Actos, and Painters and Allied Trades District Council 82 Health Care Fund ("Painters Fund") (collectively, "Plaintiffs"), a TPP that

\footnotetext{
${ }^{2} I d$. at 1246.

${ }^{3}$ Id.

${ }^{4} I d$.

${ }^{5}$ See id.

${ }^{6} \mathrm{Id}$.

${ }^{7} I d$.
} 
reimburses members covered under its plan for medical and health expenses, brought a class action suit against Defendants in the Western District of Louisiana. ${ }^{8}$ They later transferred the case to the Central District of California. ${ }^{9}$

Plaintiffs alleged that Defendants committed fraud by actively misleading doctors, patients, and TPPs into believing that Actos did not increase a user's susceptibility to bladder cancer. ${ }^{10}$ In accordance with RICO § 1964(c), Plaintiffs sought to recover economic damages incurred by their purchases of Actos in reliance on Defendants' false assertions. ${ }^{11}$ However, the court dismissed the case, stating that Plaintiffs failed to demonstrate that "Defendants' acts and omissions were the proximate cause" of their economic loss. ${ }^{12}$ Plaintiffs subsequently appealed to the U.S. Court of Appeals for the Ninth Circuit. ${ }^{13}$

The Ninth Circuit reversed the district court's ruling and found for Plaintiffs, reasoning that the proximate cause requirement described in $\S 1964(\mathrm{c})$ was satisfied because a direct relationship existed between Defendants' fraud and the economic injury suffered by TPPs. ${ }^{14}$ The court explained that even though doctors prescribed the drug, their actions did not constitute an intervening cause because it was foreseeable that on account of the structure of the U.S. healthcare system, patients and TPPs would shoulder the economic losses. ${ }^{15}$ The court further provided that even though doctors served as intermediaries, "it was perfectly foreseeable that physicians who

${ }^{8} I d$. at $1246-47$.

${ }^{9}$ Id. at 1246.

${ }^{10} \mathrm{Id}$. at 1247.

${ }^{11} \mathrm{Id}$.

${ }^{12} I d$. at 1247-48.

${ }^{13} \mathrm{Id}$. at 1248 .

${ }^{14} I d$. at 1259-60.

${ }^{15} \mathrm{Id}$. at 1257. 
[prescribed] Actos would play a causative role in Defendants' allegedly fraudulent scheme to increase Actos's revenues," meaning the chain of causation remained intact. ${ }^{16}$

\section{REVIEW OF RELEVANT CASE LAW}

To successfully establish a civil RICO claim, a plaintiff must satisfy two requirements. ${ }^{17}$ First, under 18 U.S.C. $§ 1962$ (c), the plaintiff must demonstrate that the defendant participated "in the conduct of [their] enterprise's affairs through a pattern of racketeering activity." 18 Second, under 18 U.S.C. $§ 1964(c)$, the plaintiff must prove that they were "injured in [their] business or property by reason of [defendant's] violation of section 1962."19

In Holmes v. Security Investor Protection Corp., the Supreme Court interpreted the phrase “by reason of" in $\S 1964(c)$ to mean that the defendant's violation of $\S 1962$ was the proximate cause of the plaintiff's injury, adding there must reside "some direct relation between the injury asserted and the injurious conduct alleged." 20

To determine whether a "direct relation" existed between a defendant's conduct and the plaintiff's injury, the Court considered three factors: (1) the difficulty of determining "what damages are attributable to [d]efendants' alleged RICO violation, as opposed to [independent intervening] factors"; (2) the risk of "duplicative recoveries by plaintiffs removed at different levels of injury from the violation"; and (3) "whether holding [d] efendants liable ... justifies the general interest of deterring injurious conduct or whether there are more directly injured victims

\footnotetext{
${ }^{16} \mathrm{Id}$.

${ }^{17} \mathrm{Id}$. at 1248 .

${ }^{18} 18$ U.S.C. $\S 1962(\mathrm{c})$.

${ }^{19}$ Id. § 1964(c).

${ }^{20}$ Holmes v. Secs. Inv. Prot. Corp., 503 U.S. 258, 268 (1992).
} 
we can count on to hold [d]efendants liable." 21 Although seemingly straightforward, courts are divided on how to apply these factors in cases involving TPPs and pharmaceutical companies. ${ }^{22}$

The Second Circuit disfavors allowing recovery of economic damages by TPPs when the link "between the alleged misrepresentations ... and the ultimate injury to the TPPs" is too attenuated. ${ }^{23}$ In UFCW Local 1776 v. Eli Lilly \& Co., a class of TPPs sued a pharmaceutical manufacturer for misrepresenting the side effects of their drug Zyprexa. ${ }^{24}$ The plaintiffs alleged that they suffered economic injury because they otherwise would never have purchased the drug absent the defendant's misrepresentations. ${ }^{25}$ The Second Circuit rejected this theory, holding that because the misrepresentations were not directed toward TPPs but rather doctors, who have independent knowledge of their patients and their own experience with Zyprexa, the defendant's misrepresentations were "not ... the only [or ultimate] source of information on which doctors based prescribing decisions," thereby destroying proximate cause. ${ }^{26}$

The Seventh Circuit similarly disfavors allowing recovery by TPPs when the link between the defendant's misrepresentations and the plaintiff's injury is too attenuated. ${ }^{27}$ In Sidney Hillman Health Center v. Abbott Laboratories, a class of TPPs sued a pharmaceutical manufacturer for concealing the harmful side effects of its drug from consumers. ${ }^{28}$ Relying on the same reasoning as the Second Circuit, the Seventh Circuit held that the harm TPPs suffered was too attenuated to satisfy proximate cause. ${ }^{29}$ However, the Seventh Circuit further rationalized its decision by explaining that TPPs were the inappropriate parties to bring a civil RICO claim because they were

${ }^{21}$ Id. at 269; Painters, 943 F.3d at 1251-52.

22 Painters, 943 F.3d at 1253.

${ }^{23}$ See UFCW Local 1776 v. Eli Lilly \& Co., 620 F.3d 121, 134 (2d Cir. 2010).

${ }^{24} I d$. at 129.

${ }^{25} \mathrm{Id}$. at 133.

${ }^{26} \mathrm{Id}$. at 135.

${ }^{27}$ See Sidney Hillman Health Ctr. v. Abbott Lab’ys, 873 F.3d 574, 578 (7th Cir. 2017).

${ }^{28} \mathrm{Id}$. at 575.

${ }^{29} \mathrm{Id}$. at 578 . 
"not the only, or even the most directly, injured parties" and because the "patients' health and financial costs come first in line temporally." 30

On the other hand, some courts reject the theory that intermediaries, like doctors and patients, eliminate proximate cause simply because they, rather than TPPs, were the ones who directly relied on a defendant's fraudulent misrepresentations. ${ }^{31}$

In In re Neurontin Marketing \& Sales Practices Litigation, plaintiff Kaiser Foundation Health Plan (“Kaiser”), a TPP, sued defendant Pfizer, a pharmaceutical manufacturer, for fraudulently misrepresenting the drug Neurontin as an effective treatment for off-label uses. ${ }^{32}$ When Pfizer moved to dismiss the case by arguing that too many steps occurred between its fraud and Kaiser's injury to sustain proximate cause, the First Circuit remained unconvinced. ${ }^{33}$ The court held that because Pfizer specifically targeted Kaiser in its fraudulent marketing plans for Neurontin and knew, on account of the U.S. healthcare system, that TPPs like Kaiser would foot the cost of Neurontin, the chain of causation between Pfizer's fraud and Kaiser's economic injury remained intact. $^{34}$

The Third Circuit also rejected the idea that intermediaries destroy proximate cause. ${ }^{35}$ In In re Avandia Marketing, Sales Practices \& Product Liability Litigation, a class of TPPs sued a pharmaceutical company for misrepresenting the health risks associated with the drug Avandia. ${ }^{36}$ The Third Circuit applied the direct relation test described in Holmes and held that the "conduct that allegedly caused [the] plaintiffs' injuries is the same conduct forming the basis of the RICO

\footnotetext{
${ }^{30} \mathrm{Id}$. at 576.

${ }^{31}$ Painters \& Allied Trades Dist. Council 82 Health Care Fund v. Takeda Pharms. Co., 943 F.3d 1243, 1255-56 (9th Cir. 2019), writ denied, 141 S. Ct. 86 (2020).

${ }^{32}$ In re Neurontin Mktg. \& Sales Pracs. Litig., 712 F.3d 21, 25 (1st Cir. 2013).

${ }^{33} I d$. at 38 .

${ }^{34}$ Id. at 38-39.

${ }^{35}$ In re Avandia Mktg., Sales Pracs. \& Prod. Liab. Litig., 804 F.3d 633, 645 (3d Cir. 2015).

${ }^{36}$ Id. at 636.
} 
scheme alleged in the complaint - the misrepresentation of the heart-related risks of taking Avandia that caused TPPs" to purchase the drug. ${ }^{37}$ The court also recognized that the TPP plaintiffs were the most appropriate party to sue the manufacturer because the injury they suffered "[was] an economic injury independent of any physical injury suffered by Avandia users" and “prescribing physicians did not suffer RICO injury" because of the defendant's fraud. ${ }^{38}$

Similarly, the Supreme Court has held that a defendant's fraudulent misrepresentations made to a third party do not necessarily destroy the chain of causation with the injured party. ${ }^{39}$ In Bridge v. Phoenix Bond \& Indemnity Co., the plaintiffs, a class of bidders at a county tax lien auction, sued the defendant, another bidder, for fraudulently submitting affidavits to the auctioneers that were not in his own name, enabling him to secure a larger share of the tax liens. ${ }^{40}$ The district court held for the defendant, claiming that the class of plaintiffs lacked standing because the fraudulent affidavits were made to the auction runners rather than the other bidders. ${ }^{41}$ The parties appealed the case to the Supreme Court, which held for plaintiffs. ${ }^{42}$ The Supreme Court reasoned that the plaintiffs were the immediately injured party, their "alleged injury - the loss of valuable liens-[was] the direct result of [the defendants'] fraud[,]" and "[i]t was a foreseeable and natural consequence of [the defendants'] scheme to obtain more liens for themselves[.]"43

\footnotetext{
${ }^{37} I d$. at 644 .

${ }^{38} I d$.

${ }^{39}$ Bridge v. Phx. Bond \& Indem. Co., 553 U.S. 639, 657-58 (2008).

${ }^{40} I d$. at $643-44$.

${ }^{41} \mathrm{Id}$. at 645.

${ }^{42} I d$. at 646, 661.

${ }^{43} \mathrm{Id}$. at 658.
} 


\section{CASE ANALYSIS}

\section{A. Direct Relation Test}

The Ninth Circuit's decision is correct in that it faithfully observes the direct relation test the Supreme Court unanimously expressed in Holmes. The direct relation test considers (1) the difficulty of attributing damages to defendants' alleged RICO violation, as opposed to intermediate factors; (2) the risk of multiple recoveries by plaintiffs removed at different levels of injury; and (3) "whether holding [d]efendants liable" will deter injurious conduct or whether more immediately injured parties have better standing to bring a cause of action. ${ }^{44}$

With respect to the first factor, the Ninth Circuit's decision is correct because difficulties associated with attributing damages in civil RICO cases involving TPPs should not preclude a finding of proximate cause. Unlike the Second Circuit in $U F C W$, which expressed that it would be too difficult to determine damages attributable to the pharmaceutical companies' fraud because prescribing doctors have independent knowledge regarding their patients and the drug's effectiveness, ${ }^{45}$ the Ninth Circuit determined that this calculation was by no means impossible. ${ }^{46}$ This holding is reasonable because, ostensibly, difficulty in attributing damages does not mean that it is impossible. More importantly, difficulty in attributing damages should by no means preclude a finding of proximate cause. This is especially true at the pleadings stage where discovery has not provided plaintiffs with a meaningful opportunity to gather information that could help them form a well-reasoned attribution of damages.

Regarding the second factor, the Ninth Circuit's holding is satisfactory because it correctly identified that the risk of duplicative recoveries in Painters was non-existent. Although there is

\footnotetext{
${ }^{44}$ Holmes v. Secs. Inv. Prot. Corp., 503 U.S. 258, 269 (1992); Painters \& Allied Trades Dist. Council 82 Health Care Fund v. Takeda Pharms. Co., 943 F.3d 1243, 1252 (9th Cir. 2019), writ denied, 141 S. Ct. 86 (2020).

${ }^{45}$ UFCW Local 1776 v. Eli Lilly \& Co., 620 F.3d 121, 135 (2d Cir. 2010).

${ }^{46}$ Id.; Painters, 943 F.3d at 1258.
} 
worry about recognizing the claims of indirectly harmed parties due to confusing apportionment rules at different levels of removal from the harm, this concern is misplaced. The Supreme Court in Holmes never ranked the ability of one party to recover over the other based on differing levels of removal from the alleged harm. ${ }^{47}$ Rather, the Court only held that the parties could not recover more than once for the same harm. ${ }^{48}$ Thus, in this case, the Ninth Circuit did not violate precedent when it held that two distinct classes of plaintiffs, the patients and the TPPs, were entitled to damages for the same injury stemming from the same injurious act: the defendants' fraud. ${ }^{49} \mathrm{~A}$ decision otherwise would set a harmful precedent whereby parties differently situated along the causal chain would be unable to recover damages stemming from the same harm, however slight the temporal or physical displacement between the parties might be. Such a holding would unfairly advantage one party's right to recovery over the other for the same wrong due to circumstances beyond their control.

Lastly, the Ninth Circuit's decision faithfully adheres to the third factor of the direct relation test because holding the pharmaceutical companies liable under civil RICO claims would deter similar injurious conduct in the future. Although critics of the Ninth Circuit's holding might argue that it goes too far by relaxing the proximate cause requirement, thereby opening the door to frivolous litigation, this concern as a matter of policy does not outweigh the dangers presented by letting pharmaceutical companies escape liability for such widespread fraudulent behavior. Additionally, while this case concerns purely economic injury, it is critical to remember that the defendants' conduct likely afflicted the lives of countless people. In sum, even though the Ninth Circuit's decision holds that TPPs can satisfy proximate cause under narrow circumstances, it will

\footnotetext{
${ }^{47}$ Painters, 943 F.3d at 1258.

48 See Holmes, 503 U.S. at 269 (holding that courts would need to adopt complicated rules to apportion damages amongst indirectly injured parties to prevent risk of multiple recoveries).

${ }^{49}$ Painters, 943 F.3d at 1260.
} 
go a long way in deterring such conduct in the future by holding pharmaceutical companies accountable for the totality of wrongs, both economic and physical, stemming from their actions.

\section{B. The Foreseeable and Natural Consequence Doctrine}

The Ninth Circuit's decision is satisfactory in that it adheres to the foreseeable and natural consequence doctrine expressed by the Supreme Court in Bridge. In UFCW, the Second Circuit held that, because the pharmaceutical companies directed their fraudulent statements toward physicians, the TPPs lacked standing to sue. ${ }^{50}$ However, this reasoning directly contradicts the Supreme Court's unanimous holding in Bridge, which established that direct reliance on a defendant's fraudulent misrepresentations is not necessary to denote proximate cause. ${ }^{51}$ Rather, the focus should be on whether the injury suffered by the plaintiffs was the foreseeable and natural consequence of the defendant's fraud, regardless of whether the plaintiffs relied on it firsthand. ${ }^{52}$ With Painters, the Ninth Circuit correctly applied this doctrine because TPPs almost invariably foot the cost of medications, meaning the defendants' scheme would never have worked without their participation. In other words, the defendants in Painters were liable because the injury suffered by the TPPs was not only foreseeable and natural, but it was the outcome specifically desired by the pharmaceutical companies.

Although proximate cause serves to discourage frivolous litigation and a direct reliance rule appears to further this principle, the Ninth Circuit's decision to uphold proximate cause in Painters was correct because neither Supreme Court precedent nor the RICO statute stipulates direct reliance. If the Ninth Circuit were to uphold the theory of direct reliance, it would radically constrict the RICO statute's “by reason of" requirement as injuries can, and often do, occur through

\footnotetext{
${ }^{50} U F C W, 620 \mathrm{~F} .3 \mathrm{~d}$ at 136.

${ }^{51}$ Bridge v. Phx. Bond \& Indem. Co., 553 U.S. 639, 657-58 (2008).

${ }^{52} I d$.
} 
intermediate parties. A holding by the Ninth Circuit otherwise would also restrict the ability of TPPs to recover for injuries deliberately inflicted upon them and encourage pharmaceutical companies to continue fraudulent behavior at the great cost of money and, more critically, human lives.

\section{CONCLUSION}

In holding that doctors and patients do not sever proximate cause in situations where TPPs buy fraudulently marketed drugs from pharmaceutical manufacturers, the Ninth Circuit has affirmed and strengthened the civil RICO statute while also faithfully adhering to Supreme Court precedent. As a matter of policy, the Ninth Circuit's decision is positive in that it enables civil entities to hold enterprises liable more readily for generating revenue from lies. This will help deter future injurious conduct and tip the inter-court split over the proximate cause requirement of 18 U.S.C. $§ 1964(c)$ in favor of the innocent, harmed parties. 